Prepared in cooperation with the

\title{
Sedimentation Survey of Lago Dos Bocas, Puerto Rico, June 1997
}

Water-Resources Investigations Report 98-4188

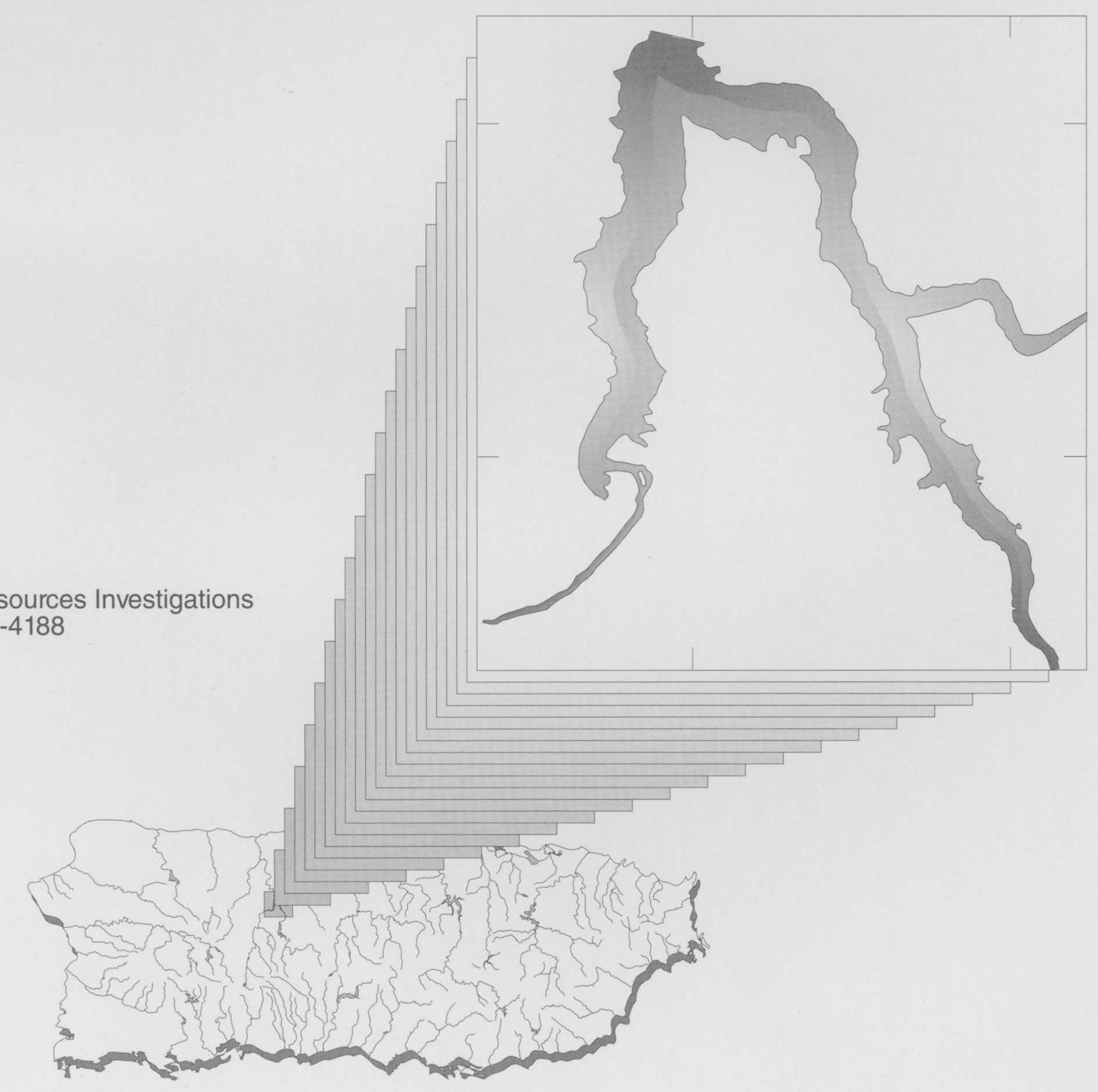




\section{Sedimentation Survey of Lago Dos Bocas, Puerto Rico, June 1997}

By Luis R. Soler-López and Richard M.T. Webb

Water-Resources Investigations Report 98-4188

In cooperation with the

PUERTO RICO AQUEDUCT AND SEWER AUTHORITY 


\title{
U.S. DEPARTMENT OF THE INTERIOR BRUCE BABBITT, Secretary
}

\author{
U.S. GEOLOGICAL SURVEY \\ Thomas J. Casadevall, Acting Director
}

Use of trade names in this report is for identification purposes only and does not imply endorsement by the U.S. Government.

For additional information write to:

District Chief

U.S. Geological Survey

GSA Center, Suite 400-15

651 Federal Drive

Guaynabo, Puerto Rico 00965-5703
Copies of this report can be purchased from:

U.S. Geological Survey

Branch of Information Services

Box 25286

Denver, CO 80225-0286 


\section{CONTENTS}

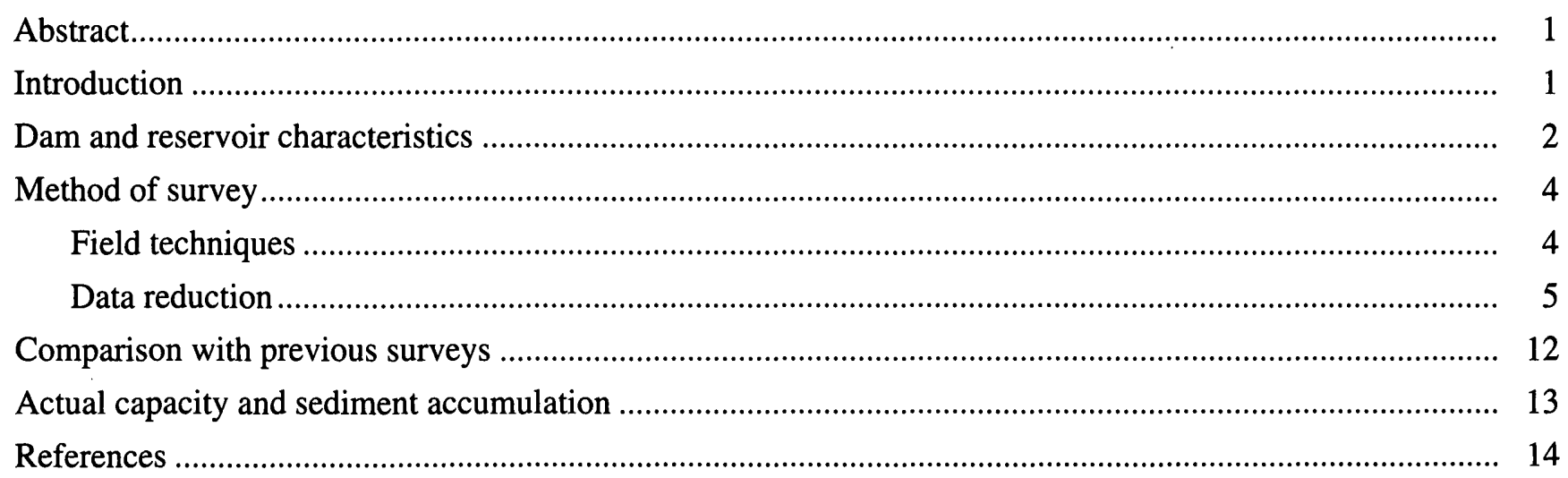

\section{PLATES}

[Plates are in pocket]

1. Lago Dos Bocas, Puerto Rico, Bathymetry, June 1997

2. Lago Dos Bocas, Puerto Rico, Elevation differences from 1994 to 1997

\section{FIGURES}

1. Map showing location of Lago Dos Bocas in the Río Grande de Arecibo basin, Puerto Rico

2. Cross-section locations and actual track lines of the 1997 bathymetric survey of Lago Dos Bocas, Puerto Rico

3. Selected cross sections generated from TIN surface model of Lago Dos Bocas, Puerto Rico, for 1994 and 1997.

4. Reference distances for longitudinal profiles shown in figure 5 and measured in Lago Dos Bocas, Puerto Rico, during the 1994 and 1997 bathymetric surveys

5. Comparison of longitudinal profiles for 1994 and 1997 along the Río Grande de Arecibo, Río Caonillas, and Río Limón branches of Lago Dos Bocas, Puerto Rico

6. Capacity curves for Lago Dos Bocas, Puerto Rico, for 1942, 1977, 1994, and 1997

\section{TABLES}

1. Principal characteristics of Lago Dos Bocas and Dos Bocas Dam ...

2. Comparison of sedimentation surveys of Lago Dos Bocas, Puerto Rico 


\begin{tabular}{rcl}
\hline Multiply & \multicolumn{1}{c}{ By } & To obtain \\
\hline centimeter & 0.32808 & foot \\
meter & 3.2808 & foot \\
kilometer & 0.62137 & mile \\
& Area & \\
square meter & 10.76 & square foot \\
square kilometer & 0.3861 & square mile \\
square kilometer & 247.10 & acre \\
& Volume & \\
cubic meters & 35.3146 & cubic feet \\
cubic meters & 810.71 & acre-feet \\
Volume per unit time (includes flow) & acre-feet \\
million of cubic meters & 0.0008107 & cubic feet per second \\
cubic meters per second & 35.3146 & gallons per minute \\
cubic meters per second & 15850 & million gallons per day \\
cubic meters per second & 22.8258 & tons per square mile \\
Mass per area (includes sediment yield)
\end{tabular}

Horizontal Datum - Puerto Rico Datum, 1940 Adjustment

Vertical Datum - National Geodetic Vertical Datum 1929 (NGVD 1929)

Megagram - One million grams

Acronyms used in this report:

$\begin{array}{ll}\text { BLASS } & \text { Bathymetric/Land Survey System } \\ \text { DGPS } & \text { Differential Global Positioning System } \\ \text { GIS } & \text { Geographic Information System } \\ \text { PRASA } & \text { Puerto Rico Aqueduct and Sewer Authority } \\ \text { PRHTA } & \text { Puerto Rico Highway and Transportation Authority } \\ \text { TIN } & \text { Triangulated Irregular Network } \\ \text { USACE } & \text { U.S. Army Corp of Engineers } \\ \text { USGS } & \text { U.S. Geological Survey }\end{array}$




\title{
Sedimentation Survey of Lago Dos Bocas, Puerto Rico, June 1997
}

\author{
By Luis R. Soler-López and Richard M.T. Webb
}

Abstract

Sedimentation has reduced the storage capacity of Lago Dos Bocas by approximately 46 percent over the last 55 years from 37.5 million cubic meters in 1942 to 20.2 million cubic meters in 1997 . The long-term sedimentation rate is calculated to be 314,000 cubic meters per year. The average sedimentation rate calculated for the 2 years and 10 months since the last bathymetric survey was completed (storage capacity as of August 1994 was 21.31 million cubic meters) is approximately 390,000 cubic meters per year. A large amount of the sediment deposited from 1994 to 1997 was transported by a single significant rainfall event that resulted from the passage of Hurricane Hortense during September 1996. During the peak discharge, the Río Grande de Arecibo was transporting approximately 16 megagrams of suspended sediment per second directly into the Río Grande de Arecibo branch of Lago Dos Bocas. Approximately 180,000 megagrams of suspended sediment coming from the Río Grande de Arecibo entered the reservoir during September 10-11, 1996. Additional sediment transported into the lake that was not measured at the suspended sediment monitoring station includes that amount of suspended sediment entering from the Río Limón branch and the coarser particles transported along the channel beds of the Río Grande de Arecibo and the Río Limón. Suspended sediment measured downstream of Lago Dos Bocas on the Río Grande de Arecibo totaled 90,000 megagrams for September 1996.
An average of 2 meters of sediment was deposited in the Río Grande de Arecibo branch from 1994 to 1997 . Little sedimentation has occurred in the Río Caonillas branch, verifying that Lago Caonillas, located immediately upstream, is a major sediment repository along the Río Caonillas tributary. In the Río Limón branch, about 1 meter of sediment has deposited in the same period of time. Excluding the Lago Caonillas drainage basin, the long-term sediment yield of the Río Grande de Arecibo drainage basin is approximately 1,000 megagrams per square kilometer per year.

\section{INTRODUCTION}

The Puerto Rico Aqueduct and Sewer Authority (PRASA) plans to withdraw water from the Río Grande de Arecibo, south of the town of Arecibo, to supply potable water for areas between Arecibo and San Juan. The amount of water that can be withdrawn from the river without significant impacts to the ground-water supplies of the area or to the surrounding wetland ecosystems depends, to a large degree, on the frequency and volume of water released from Lago Dos Bocas, a reservoir built in 1942 upstream on the Río Grande de Arecibo for hydroelectric power generation. The amount of water that can be discharged daily, without emptying the reservoir even in times of drought, is known as the firm yield. The firm yield is determined by the volume of runoff entering the reservoir during dry periods and the storage capacity of the reservoir. The passage of Hurricane Hortense in September 1996 resulted in significant sedimentation in Lago Dos Bocas. 
During June 1997, the U.S. Geological Survey (USGS), in cooperation with the PRASA, conducted a study to determine the storage capacity of Lago Dos Bocas, determine rates of storage-capacity loss, and identify the location and thickness of sediment deposited in the reservoir since the last survey in August 1994. These data will be useful in developing a strategy for using Lago Dos Bocas as a public-water supply. To accomplish these objectives, a bathymetric survey of Lago Dos Bocas was conducted in June 1997. Data on position and water depths were simultaneously collected with a Differential Global Positioning System (DGPS) and a depth sounder and then stored directly in digital form. The digitized data were transferred into a Geographic Information System (GIS) for processing and analysis. The GIS was then used to calculate storage capacity as of June 1997 and to determine the location and thickness of sediment deposited since the survey in August 1994.

\section{DAM AND RESERVOIR CHARACTERISTICS}

Lago Dos Bocas reservoir was completed in 1942. The dam is located about 9 kilometers northeast of the town of Utuado immediately downstream of the original confluence of the Río Grande de Arecibo and the Río Caonillas (fig. 1). North of the dam, the Río Grande de Arecibo meanders approximately 16 kilometers through karst terrain, crosses the coastal plain, and discharges into the Atlantic Ocean. The original capacity of the reservoir was 37.5 million cubic meters at a spillway elevation of 89.92 meters (Sheda and Legas, 1968). The principal characteristics of Lago Dos Bocas and structures are presented in table 1.

Table 1. Principal characteristics of Lago Dos Bocas and Dos Bocas Dam (Modified from Sheda and Legas, 1968)

Total length of dam at top (spillway and nonoverflow sections)... 401 meters

Length of spillway section. 110 meters

Elevation of crest of spillway above mean sea level 89.92 meters

Maximum width at base. 47 meters

Diameter of penstocks 2.74 meters

Installed power-generating capacity 22,500 kilowatts

Original maximum flood-level storage. 61.6 million cubic meters

Design discharge at a head of 8.53 meters (elevation 98.45 meters above mean sea level) 5,670 cubic meters per second

Spillway crest-level storage 37.5 million cubic meters

Surcharge storage (flood control) 24.1 million cubic meters

Drainage area at dam site ${ }^{1}$ 440 square kilometers

Design flooded area (elevation of 88.5 meters) 2.57 square kilometers

Maximum height of dam 57.3 meters

Maximum original depth of normal pool. 47.2 meters

Maximum depth during 1997 survey. 24 meters

\footnotetext{
${ }^{1}$ Includes about 130 square kilometers of Lago Caonillas drainage basin.
} 

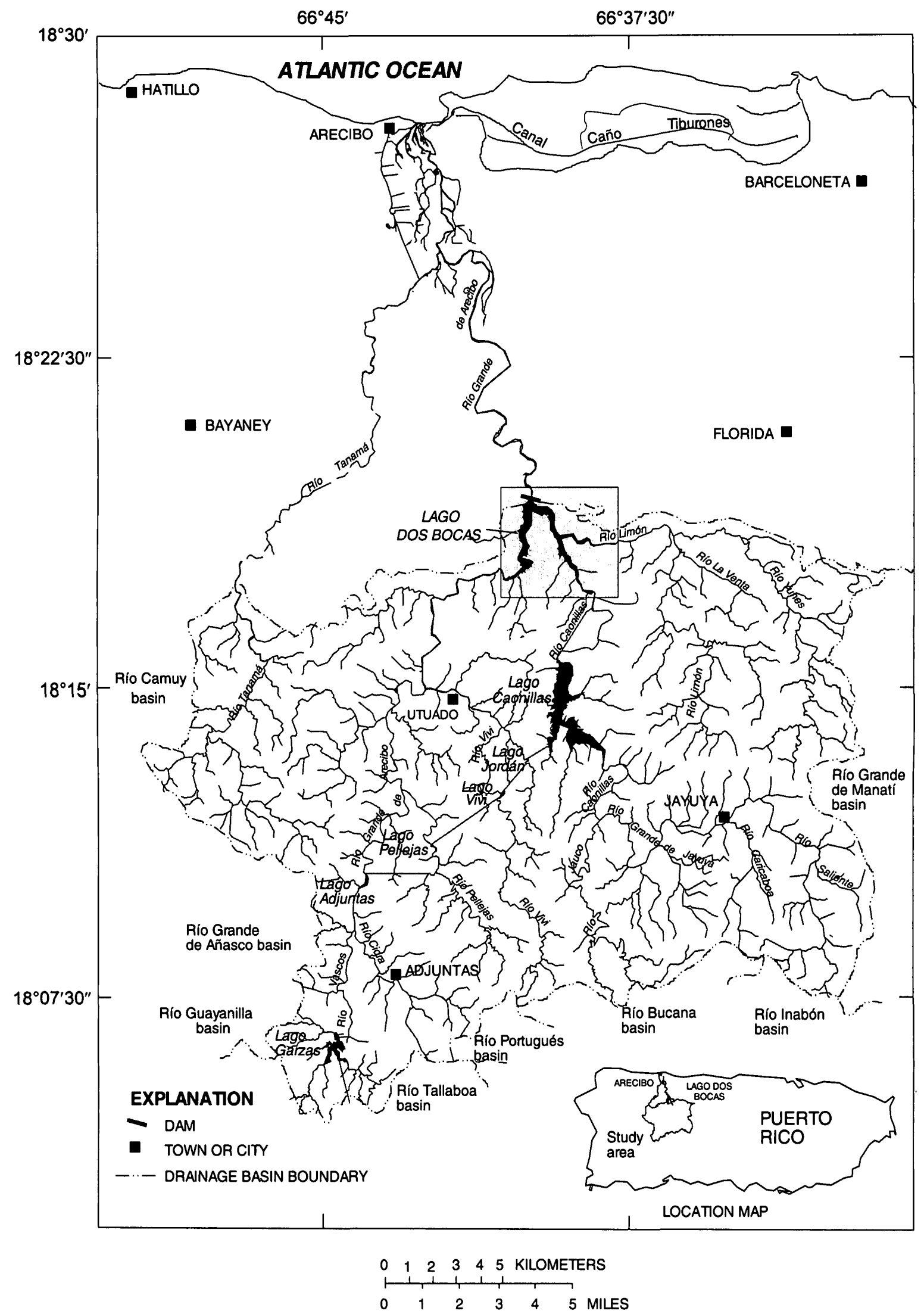

Figure 1. Location of Lago Dos Bocas in the Río Grande de Arecibo basin, Puerto Rico. 


\section{METHOD OF SURVEY}

The survey of Lago Dos Bocas included planning, data acquisition, and data processing. A GIS, Arc/Info, was used to plan the survey lines and for analysis of the bathymetric data. Cross-section locations were chosen to correspond with those surveyed by the USGS in 1994. Data were collected with a DGPS interfaced to a depth sounder. The soundings were subsequently adjusted to represent depths below the spillway elevation. Depths below spillway elevation can be converted to elevations above mean sea level (NGVD 1929) by subtracting the depth value from the spillway elevation of 89.92 meters above mean sea level. Depth contours were drawn at 5-meter intervals in steeply sloped areas and at 0.2- to 2-meter intervals in gently sloped areas. The contour lines were then converted into a surface model by creating a triangulated irregular network (TIN). The TIN represents the lake bottom as thousands of adjoining triangles with $\mathrm{x}, \mathrm{y}$, and $\mathrm{z}$ coordinates assigned to all vertices. The volume of the lake was then calculated at incremental pool elevations. Cross sections and longitudinal sections were produced from the surface models. These sections were compared with the bathymetric data to verify that the model sections accurately reflect the lake bottom. Finally, the 1994 and 1997 TIN's were converted into registered grids and the difference in elevation between the surveys for each cell was determined and used to construct a map showing the amount of sediment deposition or erosion in different areas of the reservoir during the 3-year period.

\section{Field Techniques}

The bathymetric survey took place on June 26 , 1997. The bathymetric survey used the Bathymetric/ Land Survey System (BLASS) developed by Specialty Devices, Inc. This system uses two Motorola SixGun DGPS units for horizontal positioning of the survey boat. The DGPS units were first used in static survey mode to establish a reference mark at a site near the reservoir. Satellite information was recorded simultaneously at a master station (CAGUANA USACE $18^{\circ} 18^{\prime} 25.774^{\prime \prime}$., $66^{\circ} 42^{\prime} 57.609^{\prime \prime}$ W.) and the desired reference station. A 45-minute static GPS observation session was used to establish the reference point "Lookout 1997" on a hill overlooking the reservoir (18²0'07.073”N., 66 40’34.187'W.) to control position on the Río Grande de Arecibo branch. Another reference station was established by recording 45 minutes of GPS data at the confluence of the Río Limón and Río Caonillas branches (IGUINA $18^{\circ} 19^{\prime} 30.811^{\prime \prime} N$., 66³9'20.731'”W.). The IGUINA station provided differential corrections to the survey boat while it was navigating on that part of the lake. Post-processing, using the program CentiPoint, indicated an error of less than 10 centimeters for these reference stations.

Once established, "Lookout 1997" or IGUINA was occupied as the master station and the other DGPS was installed in the survey boat as a mobile station. The DGPS on board the survey boat independently received a position every second. Once every 5 seconds, the mobile DGPS received a set of pseudo-range corrections from the master station to maintain a positional precision within 2 meters. When needed, a signal repeater was installed on a strategic point enabling continuous reception of the differential corrections.

Lake depths were measured using a RAYTHEON model DE-719B echo sounder coupled to an ODOM DIGITRACE to record data in both digital and analog form. The fathometer transducer emits a 208-kilohertz pulse with a 8-degree beam width. The echo sounder measured the depth to 5-centimeter accuracy and was calibrated in water depths of 14 and 20 meters. The bathymetric survey software HYPACK received and recorded the positions and depths once every second while in survey mode. HYPACK runs on a portable personal computer and is used both to record data and for navigation. The helmsman of the survey boat is provided with a graphical display showing the lakeshore, the planned track lines, the actual position of the boat while underway, and indicators of speed and the amount of deviation from the planned track lines. Plans were to collect sounding data at 44 cross sections. 
Eight kilometers of depth sounding data were collected on June 26, 1997 (fig. 2). Data for cross sections 32 to 36 were collected while technicians navigated the boat through the narrow sediment-filled riverine section. No data were collected for cross sections 37 to 44 because the water was too shallow. Data were not collected for cross sections 16 and 17 because of equipment failure at the end of the surveying work. Only limited sediment deposition was documented for the period 1977 to 1994 by the previous study (Webb and Gómez-Gómez, 1996) and, therefore, the authors decided it was unnecessary to return to the lake to collect depth soundings for sections 16 and 17 once the equipment was repaired. Ancillary data were collected by looping around a concrete structure near the public boat ramp at the beginning and at the end of every workday to verify positional accuracy.

Transient errors in positional data could occur because of GPS calculation errors; errors in depth data could occur because of bubbles on the transducer face or insufficient signal gain. Physical or electronic problems encountered in the field were corrected as soon as they were detected. If the amount of missing or erroneous data occurred for more than 20 meters along the cross section, that section was rerun. If the amount of erroneous data occurred for less than 20 meters along the cross section, and the bottom was flat or exhibited no change in slope before and after the section in which data were lost, the section was not rerun but the data file were flagged for later editing.

\section{Data Reduction}

Initial editing with verification of the positional and depth data was performed within the HYPACK program. Positions were corrected to eliminate anomalous spikes and translate data to estimated positions when the differential correction signal was lost for a large amount of time.

Spikes or jumps in the positional data may occur when the satellite signal is obstructed by local topographic features or disrupted by spurious electromagnetic interference. When this occurs, a position may be calculated that is several hundred meters from previous or subsequent point. In these cases, the positions were interpolated to the midpoints between the continuous positions.

When elevated land surfaces between the boat and the master station blocked the correction signal on the Río Grande de Arecibo and the Río Caonillas branches, the signal repeater was then installed to "bounce" the signal into the mobile DGPS on the boat. At all times during the June 1997 survey, differential corrections were received either directly from the master station or from the repeater station.

The pool elevation during the day of the survey (June 26) rose from 88.65 to 88.68 meters above mean sea level. To correct the data collected to the actual spillway elevation of 89.92 meters above mean sea level, a time-elevation correction factor was used. The edited data were then transferred into the GIS. Contour lines of the lake bottom were produced manually in the GIS by color coding the individual sounding values to reflect different depths.

The contour map (plate 1) was used to create the TIN surface model of the 1997 lake bottom. The base map for the 1997 lake boundary used in the contour map was modified from that reported for the 1994 survey. Initially, the bottom contours were drawn at intervals of 5 meters; additional contour lines with smaller intervals were added to present greater detail in areas where changes were more subtle. Cross section an longitudinal profiles were calculated from the TIN surface model (fig. 3 ).

Distances upstream from the dam were calculated from the thalweg of the river branches (fig. 4). Longitudinal profiles showing the differences in elevations between the 1994 and the 1997 lake bottoms are presented in figure 5 . The gross depositional pattern of sedimentation in the Río Grande de Arecibo branch and little sedimentation in the Río Caonillas branch of Lago Dos Bocas is clearly evident. 


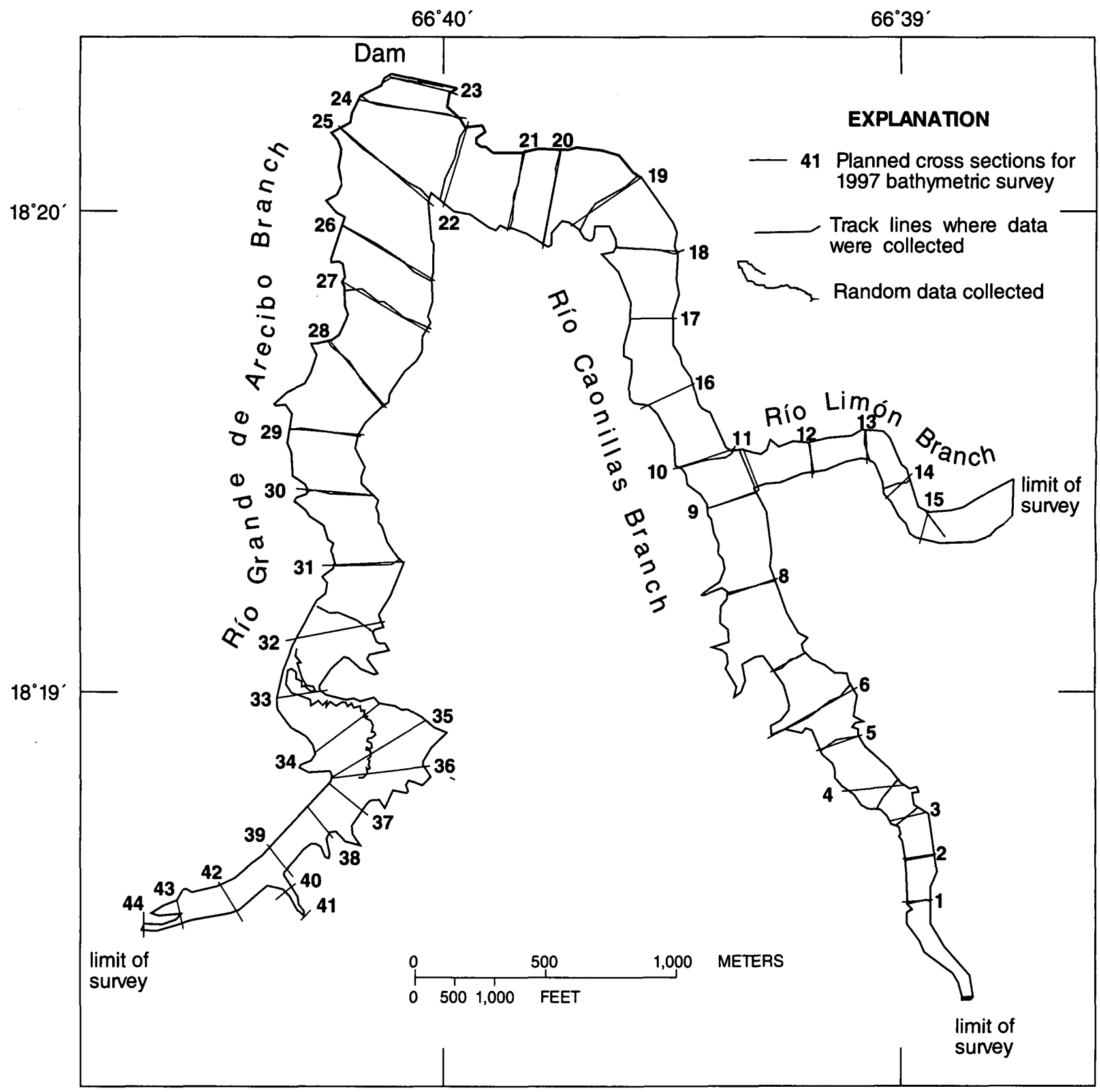

Figure 2. Cross section locations and actual track lines of the 1997 bathymetric survey of Lago Dos Bocas, Puerto Rico. 

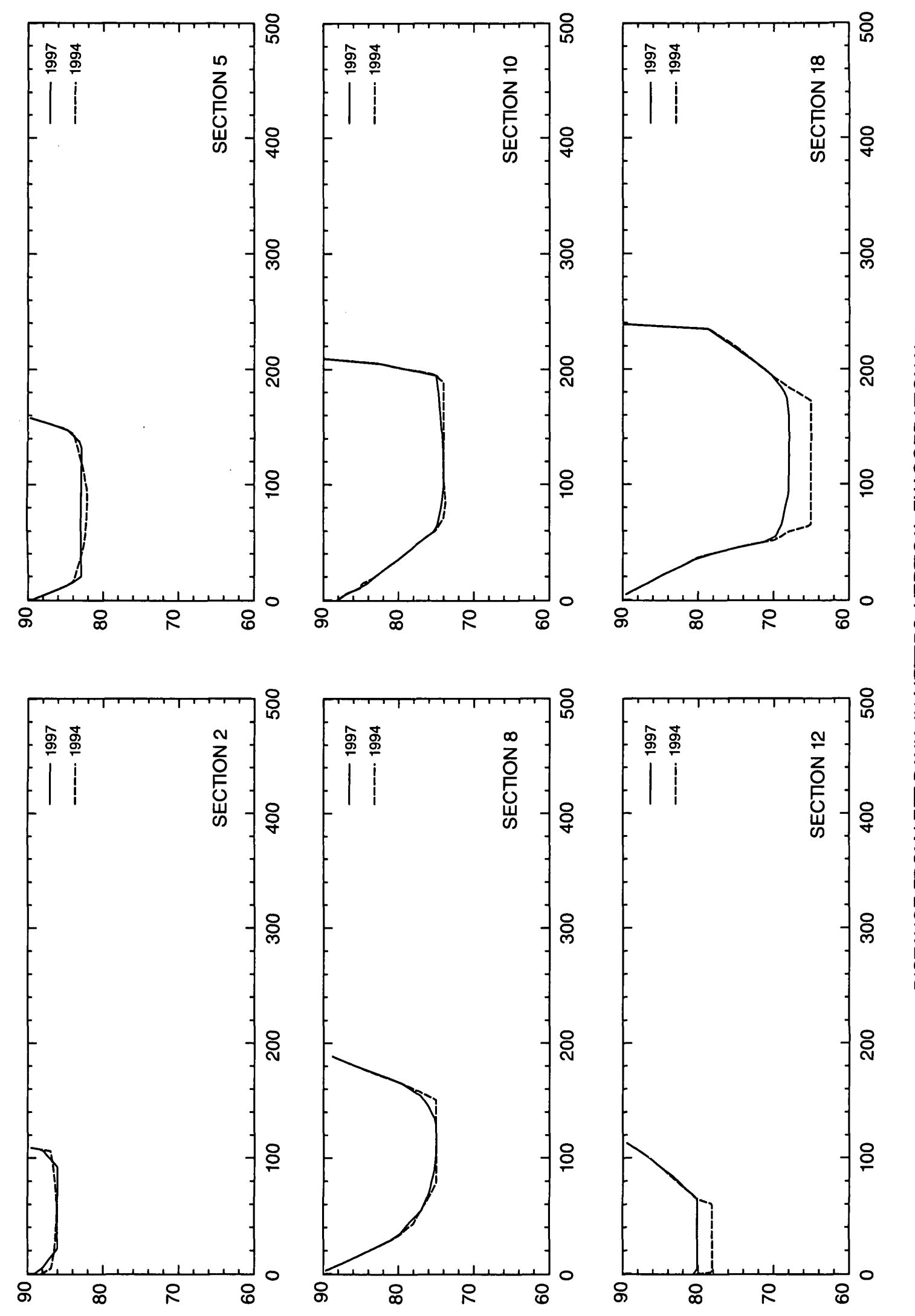

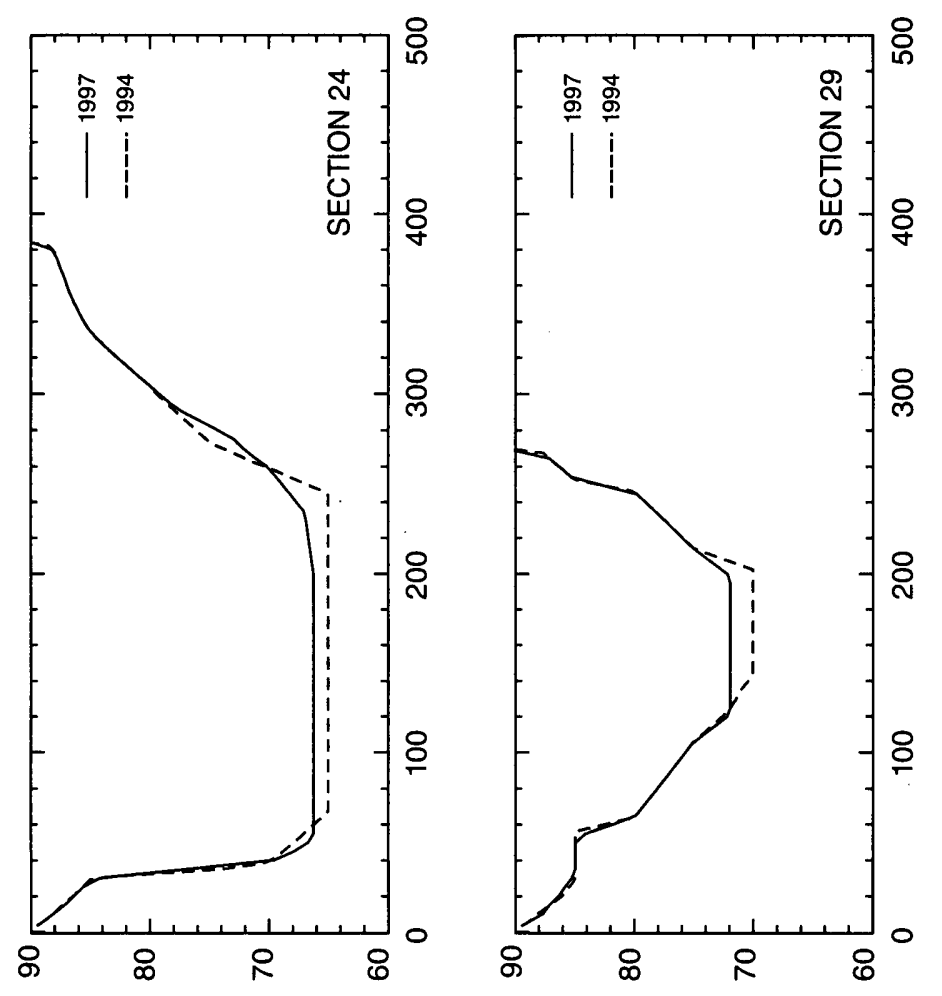

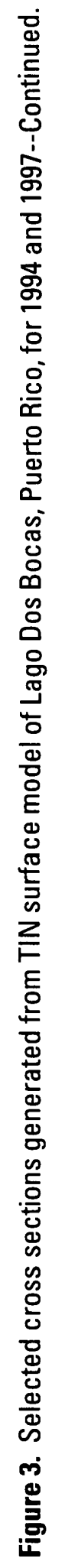

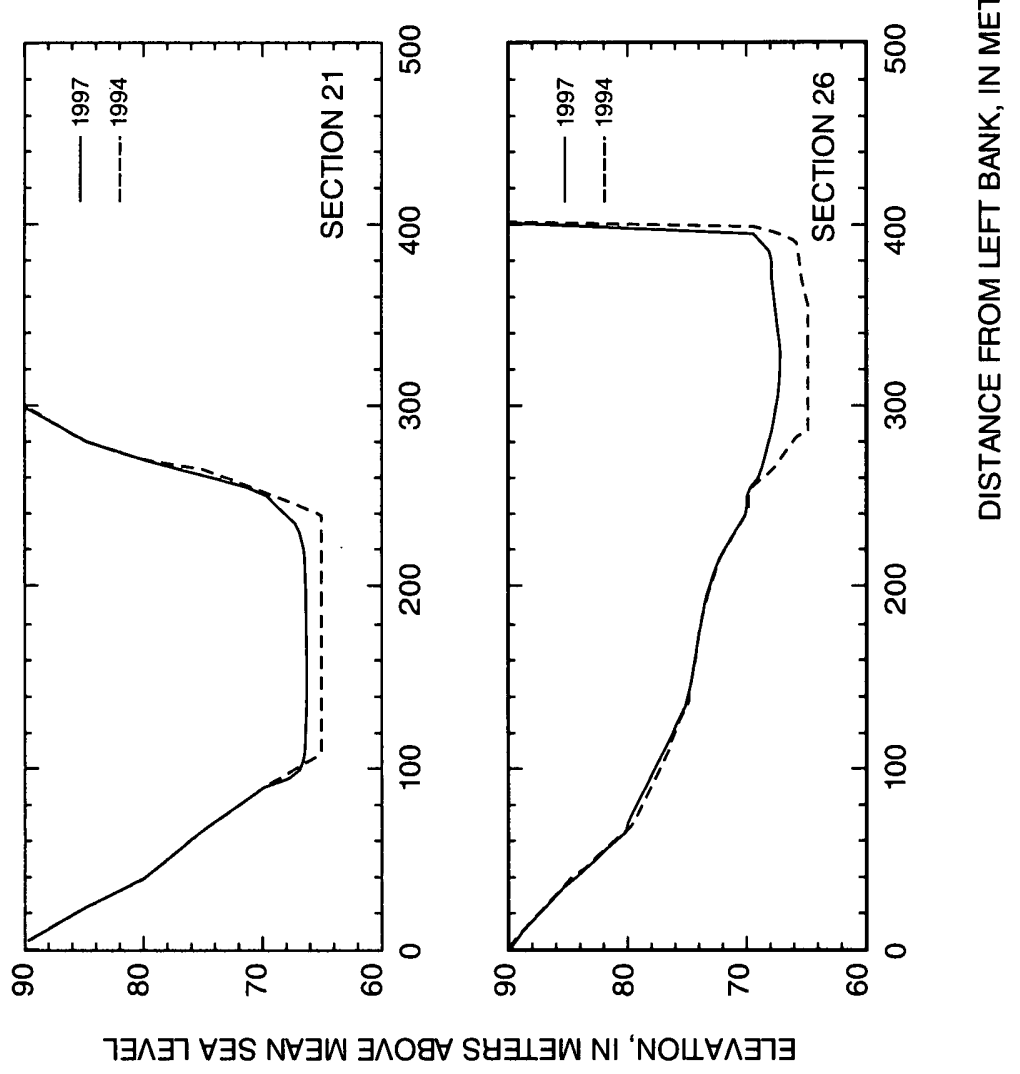



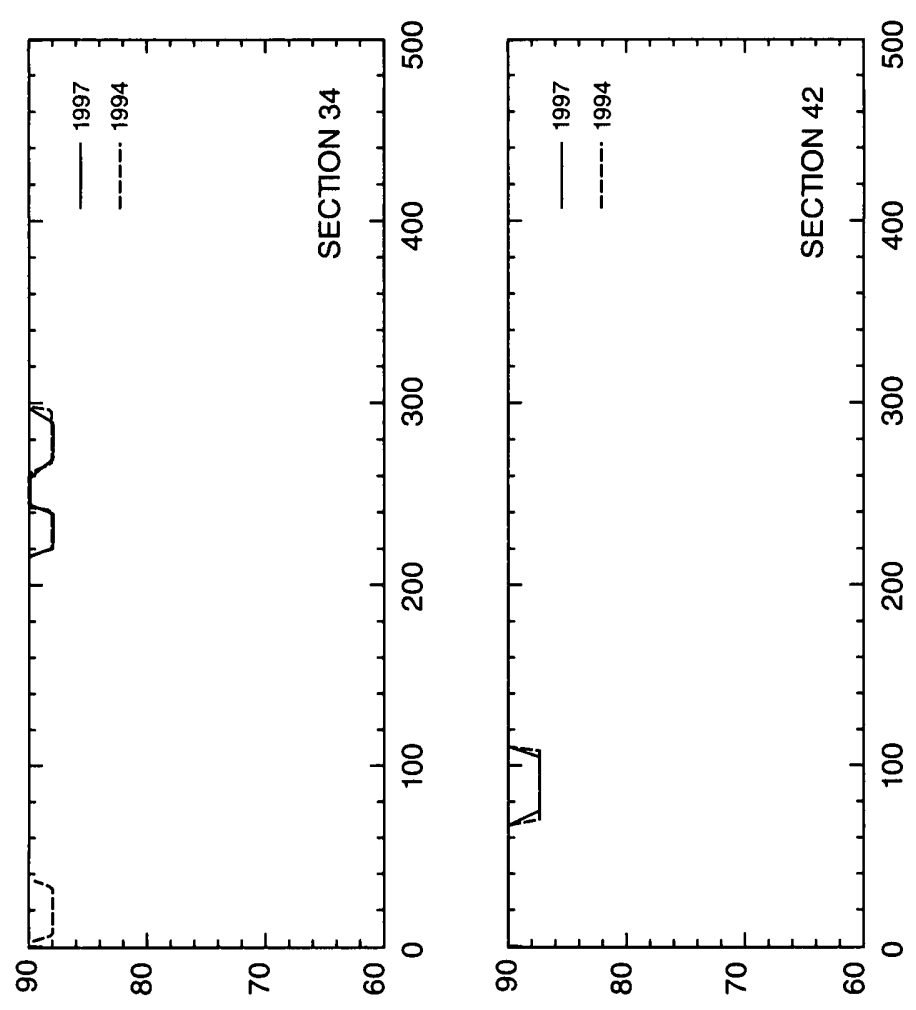

通

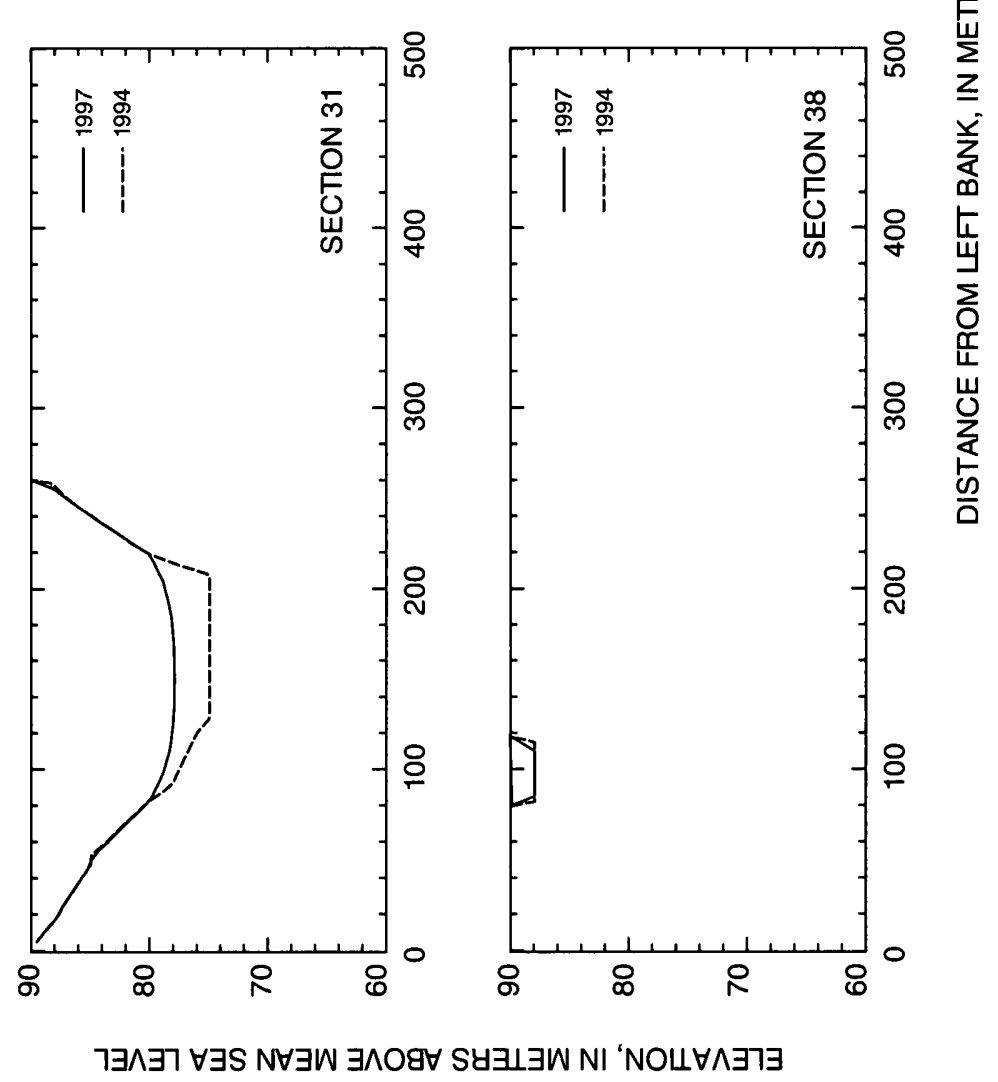




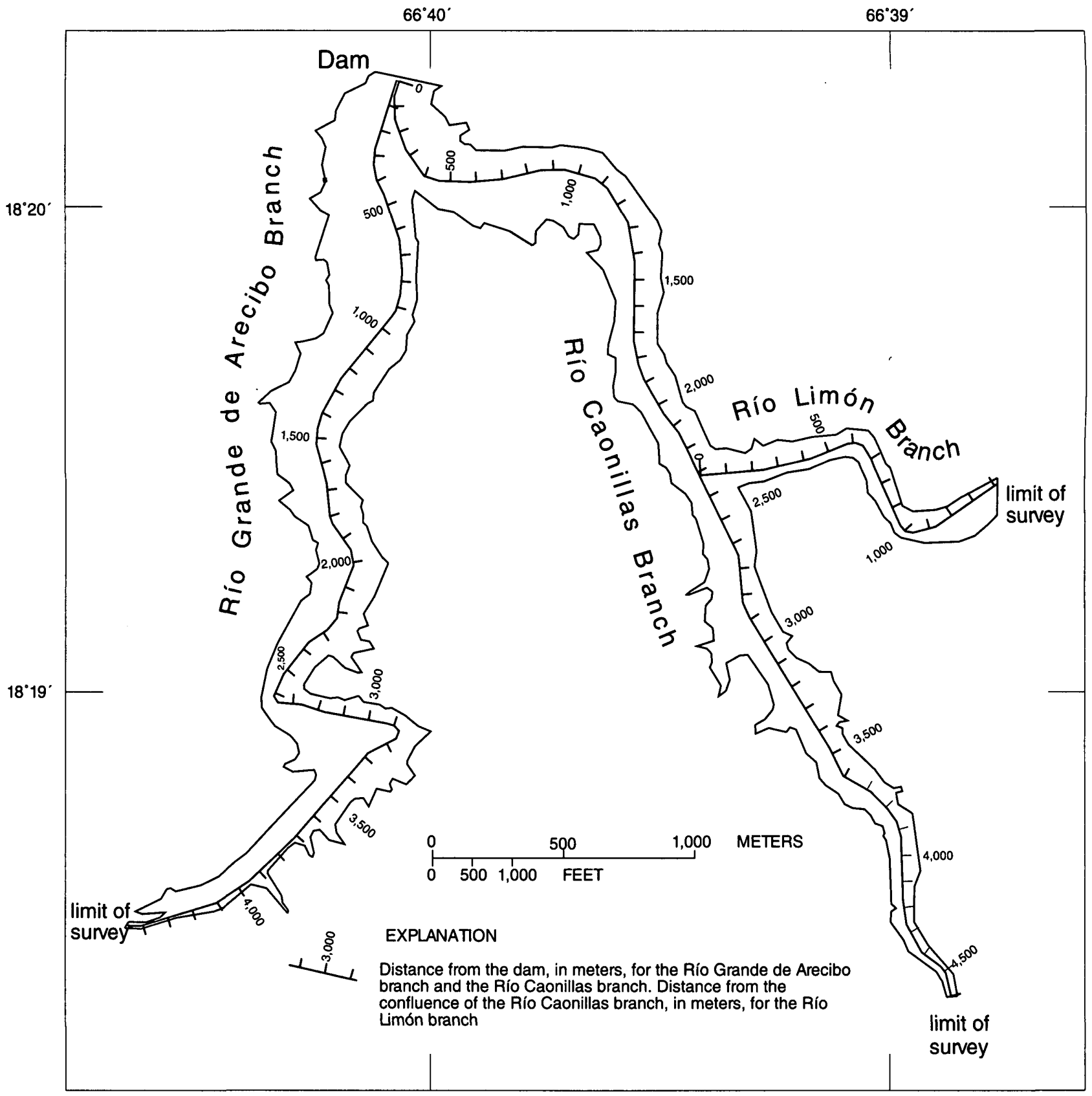

Figure 4. Reference distances for longitudinal profiles shown in figure 5 and measured in Lago Dos Bocas, Puerto Rico, during the 1994 and 1997 bathymetric surveys. 


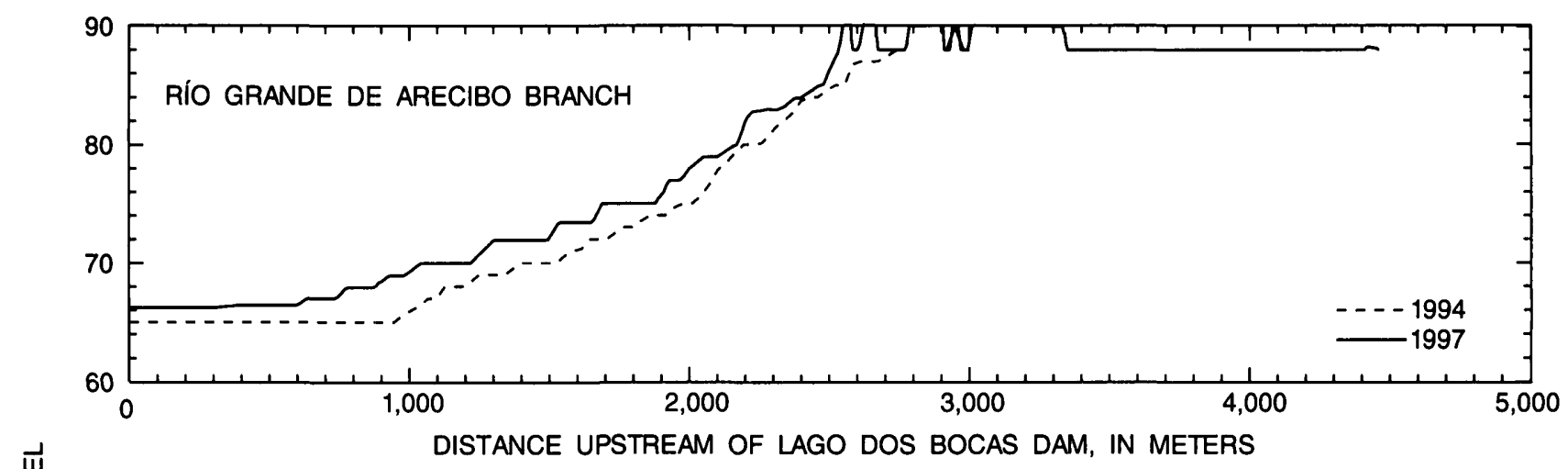

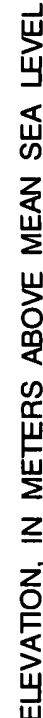
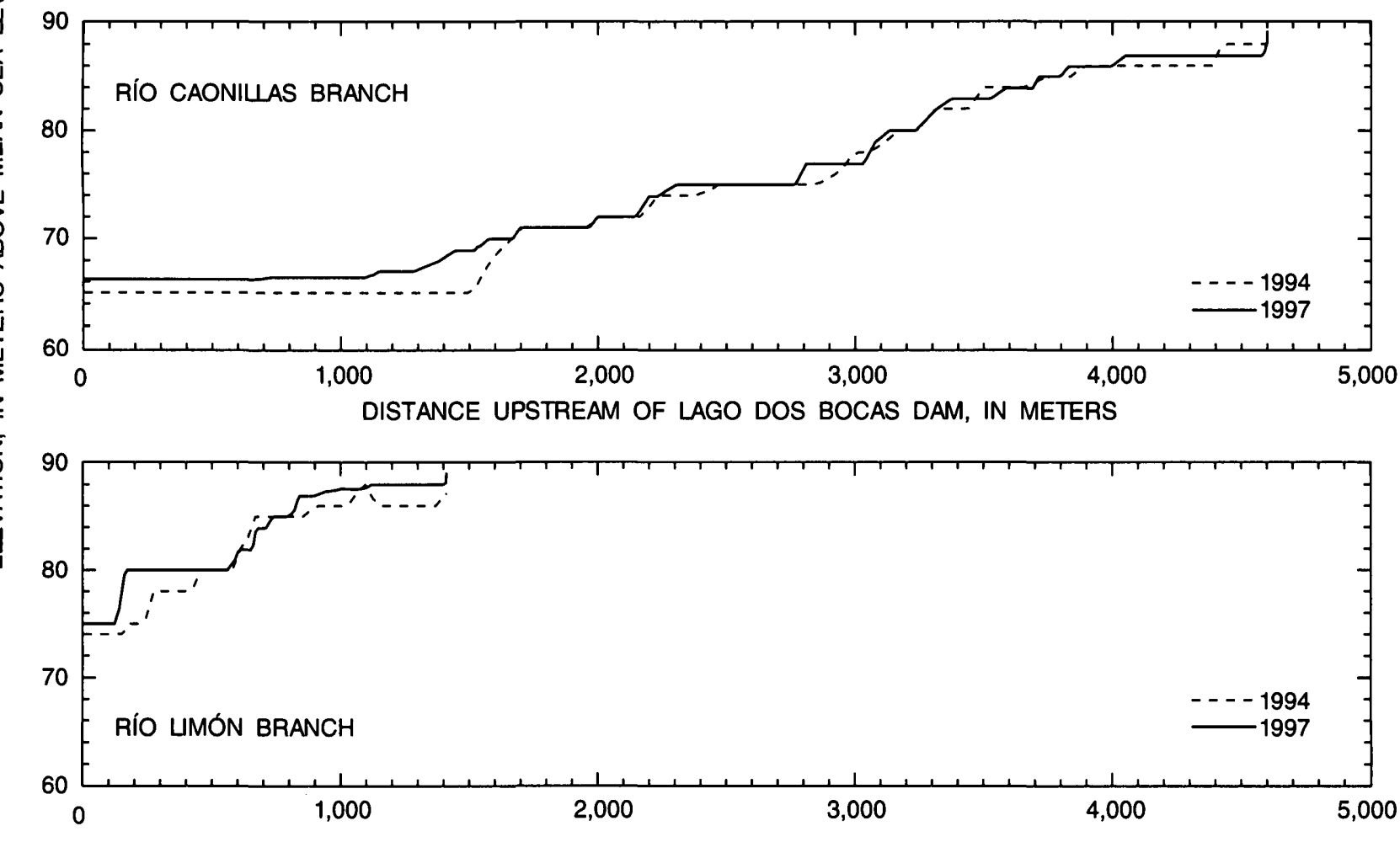

DISTANCE UPSTREAM OF THE RÍO CAONILAS BRANCH OF LAGO DOS BOCAS, IN METERS

Figure 5. Comparison of longitudinal profiles for 1994 and 1997 along the Río Grande de Arecibo, Río Caonillas, and Río Limón branches of Lago Dos Bocas, Puerto Rico. 


\section{COMPARISON WITH PREVIOUS SURVEYS}

Lago Dos Bocas was surveyed by the Water Resources Authority of Puerto Rico at the time the dam was under construction in 1942 (original records were not available at the time of this report). The next survey was conducted by the USGS in 1977 for an unpublished report. The contour map of that survey was made available for comparison with the present survey. Both the 1977 survey and the 1985 survey by Quiñones and others (1989) used precision survey echo sounders to measure water depths. Velocity meters were used to determine distances from the bank and to mark the section record. The 1977 survey used the modified prismoidal formula to calculate incremental estimates of volume for the reservoir based on the area of the reservoir at three elevations (Heinemann and Dvorak, 1963). The 1985 survey estimated the volume using the "range method" (Soil Conservation Service, 1983). The 1994 and the 1997 volumes were calculated using the respective 1994 and 1997 TIN's. A comparison of prior and current sedimentation surveys of Lago Dos Bocas is presented in table 2 .

Volume calculations can vary as much as 10 percent for small reservoirs depending on the method, the quantity and orientation of the ranges (Heinemann and Dvorak, 1963). For the present study, GIS algorithms were used to calculate volume of the surface model represented by the 1997 contour map (Environmental Systems Research Institute, Inc., 1992).

Table 2. Comparison of sedimentation surveys of Lago Dos Bocas, Puerto Rico

[All capacities are shown in millions of cubic meters. Elevation datum, National Geodetic Vertical Datum 1929; TIN, triangulated irregular network; --, no data available or undetermined]

\begin{tabular}{|c|c|c|c|c|c|}
\hline & 1942 & ${ }^{1} 1977$ & ${ }^{2} 1985$ & 1994 & 1997 \\
\hline Total capacity & 37.50 & 27.14 & 24.20 & 21.31 & 20.23 \\
\hline $\begin{array}{l}\text { Live storage (above penstock crown at elevation } \\
71.5 \text { meters) }\end{array}$ & 29.47 & 23.13 & -- & 19.15 & 18.68 \\
\hline $\begin{array}{l}\text { Dead storage (below penstock crown at elevation } \\
71.5 \text { meters) }\end{array}$ & 7.83 & 4.01 & -- & 2.16 & 1.55 \\
\hline Years since construction & 0 & 35 & 43 & 52 & 55 \\
\hline Sediment accumulated (millions of cubic meters) & -- & 10.36 & 13.3 & 16.19 & 17.27 \\
\hline Storage loss (percent) & -- & 27.6 & 35.5 & 43.2 & 46 \\
\hline Annual loss of capacity (percent) & -- & 0.79 & 0.82 & 0.83 & 0.84 \\
\hline $\begin{array}{l}\text { Rate of capacity loss since previous survey } \\
\text { (millions of cubic meters per year) }\end{array}$ & -- & 0.296 & 0.368 & 0.321 & 0.367 \\
\hline $\begin{array}{l}\text { Long-term rate of capacity loss (millions of cubic } \\
\text { meters per year) }\end{array}$ & -- & 0.296 & 0.309 & 0.311 & 0.314 \\
\hline Year reservoir projected to fill & -- & 2069 & 2063 & 2062 & 2061 \\
\hline
\end{tabular}

\footnotetext{
${ }^{1}$ Unpublished 1977 survey by Gómez-Gómez. Year of survey erroneously listed as 1979 in Quiñones and others (1989).

${ }^{2}$ Quiñones and others (1989).
} 


\section{ACTUAL CAPACITY AND SEDIMENT ACCUMULATION}

The capacity of Lago Dos Bocas was computed to be 20.23 million cubic meters for June 1997. A large fraction of the 1.08 million cubic meters of sediment deposited since the last bathymetric study in 1994 was transported and deposited by the runoff generated by the intense rainfall that resulted from the passage of Hurricane Hortense over Puerto Rico. Hurricane Hortense brought about 200 to 400 millimeters of rain into the Río Grande de Arecibo basin upstream of Lago Dos Bocas (Torres-Sierra, 1997). On September 10,1996 , a peak discharge of 730 cubic meters per second was recorded on the streamflow and suspended-sediment monitoring station on the Río Grande de Arecibo (station 50024950) located about 4 kilometers upstream of Lago Dos Bocas. During the peak discharge, about 16 megagrams of suspended sediment per second were discharging into the Río Grande de Arecibo branch of Lago Dos Bocas. The total load of suspended sediment discharged into Lago Dos Bocas by the Río Grande de Arecibo from September 10 to September 11, 1996 was estimated to be 180,000 megagrams. Additional sediment entering the Río Limón and the Río Caonillas branches was not measured.The total amount of suspended sediments measured downstream of Lago Dos Bocas on the Río Grande de Arecibo above Arecibo surface-water and sediment station (50027750) was 90,000 megagrams for the month of September 1996.

Capacity curves for 1977, 1994, and 1997 were produced by calculating the TIN's volume at 0.3048-meter intervals from the deepest part of the reservoir measured in the 1977 bathymetric survey (61 meters above mean sea level) to the spillway elevation of 89.92 meters. The capacity curves for $1942,1977,1994$, and 1997 are shown in figure 6. The 1942 stage-storage curve was supplied by the Puerto Rico Electric Power Authority. The penstocks leading to the Dos Bocas Hydroelectric Plant have a crown elevation of 71.5 meters above mean sea level. Dead storage (the storage capacity below 71.5 meters) decreased from 7.83 million cubic meters when the dam was constructed in
1942 to 4.01 million cubic meters in 1977 , to 2.16 million cubic meters in 1994, and 1.55 million cubic meters in 1997. This represents an 80 percent dead storage loss in 55 years.

An average of 2 meters of sediment was deposited in the Río Grande de Arecibo branch of Lago Dos Bocas from 1994 to 1997 (plate 2; fig. 5). The Caonillas reservoir acts as an effective sediment trap, passing insignificant quantities of sediment to Lago Dos Bocas. Little sediment has deposited in the Río Caonillas branch of Lago Dos Bocas upstream of the Río Limón (fig. 5). Sediment deposition is only noticeable in the Río Caonillas branch of Lago Dos Bocas at and downstream of the Río Limón where an average of 1.5 meters of sediment has deposited from 1994 to 1997. In the Río Limón branch about 1 meter of sediment has been deposited in the same period.

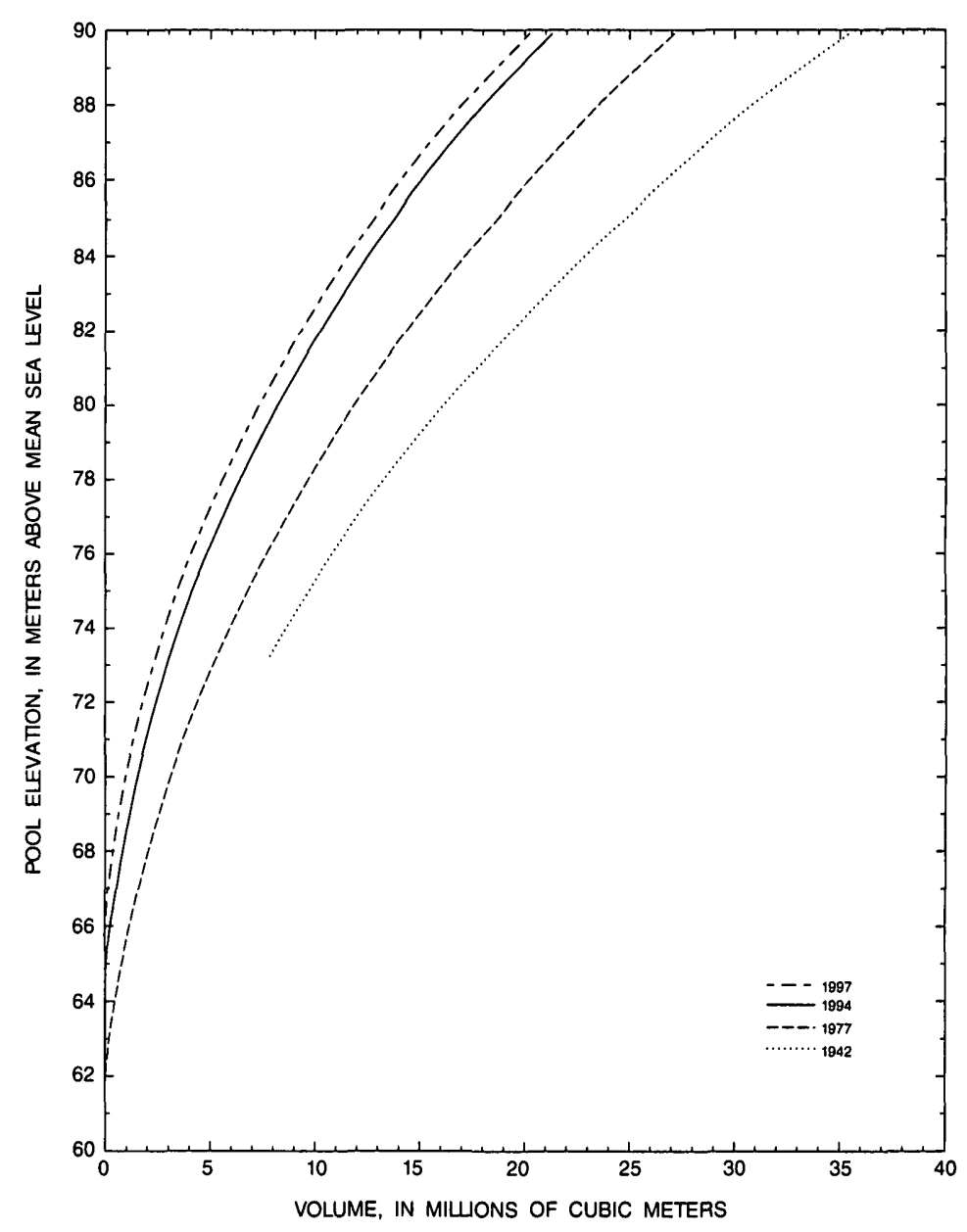

Figure 6. Capacity curves for Lago Dos Bocas, Puerto Rico, for 1942, 1977, 1994, and 1997. 
Excluding the drainage basin upstream of the Caonillas dam (130 square kilometers), the remaining area draining into Lago Dos Bocas (310 square kilometers) has yielded a minimum of 1,000 megagrams per square kilometer per year (assuming a dry bulk density of reservoir sediment of 1,000 kilograms per cubic meter). This is a conservative estimate because it includes only sediment deposited in the reservoir. However, the Caonillas dam was not completed until 1948 and significant quantities of sediment may have entered Lago Dos Bocas between 1942 and 1948.

The trap efficiency of a reservoir depends primarily on the volume of the reservoir and the mean annual runoff (Brune, 1953). On the basis of the 1997 capacity of 20.23 million cubic meters and a mean annual runoff of 400 million cubic meters (Quiñones and others, 1989) the capacity-inflow ratio of Lago Dos Bocas is 0.050 . The trap efficiency using relations established by Brune (1953) is about 78 percent. The trap efficiency could be as low as 68 percent if inflowing sediment is colloidal or very-fine-grained or as high as 88 percent if the inflowing sediment is mostly silt and sand.

\section{REFERENCES}

Brune, G.M., 1953, Trap efficiency of reservoirs: Transactions of the American Geophysical Union, v. 34, no. 3, p. 407-418.

Environmental Systems Research Institute, Inc., 1992, Surface modeling with TIN, Surface analysis and display: Redlands, California, 8 chapters.

Heinemann, H.G., and Dvorak, V.I., 1963, Improved volumetric survey and computation procedures for small reservoirs: U.S. Department of Agriculture Miscellaneous Publication 970, Symposium 4--Sedimentation in reservoirs, p. 845-856.

Quiñones, Ferdinand, Meléndez, Frank, and Bonnet, Carlos, 1989, Sedimentation survey of Lago Dos Bocas, Puerto Rico, June 1985: U.S. Geological Survey Open-File Report 86-241, 14 p.
Sheda, H.E., and Legas, James, 1968, Condition of Dos Bocas Dam, Puerto Rico, in Condition of concrete dams in Puerto Rico: U.S. Department of the Interior, Bureau of Reclamation, chap. 17, 17 p., 6 pls.

Soil Conservation Service, 1983, National engineering handbook: Section 3, Sedimentation: Chapter 7, Field Investigations and Surveys, Washington, D.C., p. 7-1 to 7-41.

Torres-Sierra, Heriberto, 1997, Hurricane HortenseImpact on surface water in Puerto Rico: U.S. Geological Survey Fact Sheet FS-014-97, 4 p.

Webb, R.M.T., and Gómez-Gómez, Fernando, 1996, Sedimentation survey of Lago Dos Bocas, Puerto Rico, August 1994: U.S. Geological Survey Water-Resources Investigations Report 95-4214, 20 p., 3 pls. 
District Chief

Caribbean District

U.S. Geological Survey

Water Resources Division

GSA Center, Suite 400-15

651 Federal Drive

Guaynabo, Puerto Rico 00965-5703

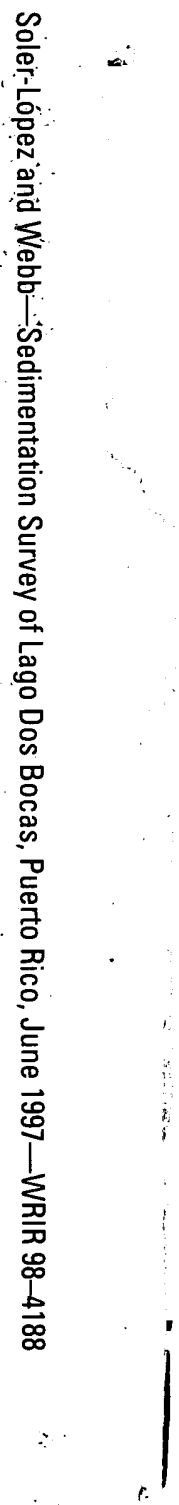

